Mini Review

\title{
Biosensors Based on Semiconductors, a Review
}

\author{
Miroslav Pohanka ${ }^{*}$ and Jan Leuchter ${ }^{2}$ \\ ${ }^{1}$ Faculty of Military Health Sciences, University of Defense, Trebesska 1575, Hradec Kralove, Czech \\ Republic; \\ ${ }^{2}$ Faculty of Military Technology, University of Defense, Brno, Czech Republic \\ *E-mail: miroslav.pohanka@gmail.com
}

doi: $10.20964 / 2017.07 .52$

Received: 13 April 2017 / Accepted: 5 May 2017 / Published: 12 June 2017

\begin{abstract}
Semiconductors are important materials in the current technology where they are implemented to electronic devices as attenuators but they can play also a role as sensors. In the current review, semiconductors are presented as a platform for the construction of biosensors and biosensor like devices serving as detectors in the analytical chemistry. Biosensors using ion sensitive field effect transistors, light addressable potentiometric sensors and analytical devices based on quantum dots are presented here. Survey of the current literature is provided and discussion about each analytical method is given here. Future trends in the biosensors based on semiconductors are also outlined.
\end{abstract}

Keywords: biosensor; immunosensor; ion sensitive; field effect transistor; light addressable potentiometric sensor; potentiometry; quantum dot

\section{FULL TEXT}

(C) 2017 The Authors. Published by ESG (www.electrochemsci.org). This article is an open access article distributed under the terms and conditions of the Creative Commons Attribution license (http://creativecommons.org/licenses/by/4.0/). 